\title{
COMPARATIVE STUDY OF SILICONE-BASED SOFT LINER VERSUS VERSACRYL LINER FOR MANDIBULAR COMPLETE DENTURE CASES (RANDOMIZED CLINICAL TRIAL)
}

\author{
Mennatallah Mohammed Moustafa Shalabi*, Essam Adel Aziz ${ }^{* *}$ \\ Nagla M.H. Nassouhy ${ }^{* * *}$ and Nermine Rouf Amin ${ }^{* * * *}$
}

\begin{abstract}
A randomized clinical trial was carried out to compare between conventional silicone-based soft liner and Versacryl lining material for the relining of mandibular complete dentures in flat mandibular cases regarding oral health related quality of life and tissue keratinization index. Twentyeight patients were distributed randomly into two groups (fourteen per group). After taking the relining impression for their existing mandibular dentures, the control group received conventional silicone based soft liner, while the intervention group received Versacryl lining material. Patients were evaluated at two weeks, two months and four months intervals. The results showed a significant difference between the two groups at two weeks and two months as the Versacryl relined dentures provided a better improvement in oral health related quality of life, while at four months there was no difference between the two groups. This study also showed a significant difference in parakeratization activity between the two groups at all follow up periods with the highest mean score in the Molloplast-B liner group.
\end{abstract}

KEYWORDS: complete denture, silicone-based soft liners, oral health related quality of life, keratinization area percent.

\section{INTRODUCTION}

Resilient liners are a group of materials that intend to increase the tolerance and comfort for complete denture wearers. They were introduced in the 1950s and have been used since then in the fitting surface of the dentures to provide a temporary or permanent "cushion like" effect and to provide better visco-elastic grip. ${ }^{1}$

There are many clinical applications of permanent resilient liners. They are considered one of the most important treatment modalities for edentulous patients with atrophic residual ridges.

\footnotetext{
* MDS Student Department of Removable Prosthodontics, Faculty of Dentistry, Cairo University.

** Professor of Removable Prosthodontics, Faculty of Dentistry, Cairo University.

*** Ass. Professor of Removable Prosthodontics, Faculty of Dentistry, Cairo University.

***** Ass. Professor of Oral and Maxillofacial Pathology, Faculty of Dentistry, Cairo University
} 
Residual ridge atrophy has been a clinical challenge for a successful prosthodontic treatment. It results in a more constricted residual ridge, decreased supporting tissue and increased restorative interarch space. The progressive increase in inter-arch space is accompanied with unstable and nonretentive dentures ${ }^{2}$. It was found that the use of resilient liners in atrophic ridge cases allows repair for abused mucosa and better force distribution with an improvement in the denture adaptation, retention and patient general satisfaction. ${ }^{3}$

Resilient liner materials, as any material, have some problems such as residual monomer, loss of resilience, water sorption, fungal accumulation, color change, and loss of adhesion between the liner and denture base resin. Bonding of silicone-based liners to denture base is a significant problem as it depends completely on a solvent. Failure in bonding between the liner and denture makes an interface for microleakage, calulus and plaque. ${ }^{4}$

Versacryl is a flexible biocompatible material with a reported predictable long term performance, durable bonding to acrylic denture bases, high fatigue endurance, excellent wear characteristics and solvent resistance with almost no free monomer in the processed material.The absence of porosity in the material reduces the biologic build up, water sorption, odors and stains, thereby allowing for a better dimensional and color stability. ${ }^{5}$

Versacryl is used to construct different parts of partial and complete dentures. It can be used as a thermo-elastic liner and its consistency can be manipulated to fit the reline to each individual case, by adding or subtracting drops of liquid B, as explained in the directions for use. The reline can be repeatedly re-adapted even by the patient when needed ${ }^{6}$.

Keratinization of the alveolar ridge mucosa could result from ordinary denture support, mechanical irritation of the dentures, accumulation of microbial plaque on dentures or occasionally a toxic or allergic reaction to denture base materials ${ }^{7,8}$. Increased keratinization following the wearing of dentures for three months was observed and it was concluded that dentures appeared to stimulate keratinization ${ }^{9}{ }^{\prime}$.

\section{MATERIALS AND METHODS}

\section{Clinical procedure}

Twenty-eight complete denture wearers were selected from the outpatient clinic of Prosthodontic Department, Faculty of Dentistry, Cairo University. Their main complaint is the inability to use the mandibular denture because of pain and/or lack of retention. This study was designed to be a parallel randomized controlled trial. The patients were randomly assigned to either one of the following groups:

- (Group I): Patients' mandibular dentures were relined using heat-cure silicone based soft liner (Malloplast B) * according to manufacturers' recommendations and a standardized curing cycle.

- (Group II): Patients' mandibular dentures were relined using heat cured Versacryl lining material ${ }^{\dagger}$ according to manufacturers' recommendations and standardized curing cycle.

An initial evaluation was conducted to determine whether the patient met the study inclusion criteria. This evaluation consisted of a medical history questionnaire, clinical examination and full mouth panoramic radiography.

Pressure indicating paste was used in the fitting surface of the old dentures to inspect the presence of any pressure areas. The old mandibular dentures were removed from the oral cavity then cleaned by brushing. The borders were shortened 2-3 $\mathrm{mm}$ for the molding material and were squared to support

\footnotetext{
* Molloplast B,DETAX, Germany

$\uparrow$ Versacryl, Keystone,USA
} 
the molding material. Any undercuts in the flanges were removed.

Border molding using green stick compound1 was done. Then, a mix of zinc oxide/eugenol was applied to the fitting surface to make the final impression. The denture was seated in the mouth and the patient was asked to occlude the maxillary and mandibular dentures while the movements of the muscles, cheeks and lips were preformed till complete setting of the impression material (Fig 1). The final impressions were poured into type III dental stone. In the laboratory, dentures were flasked in the conventional manners. After the plaster was set, the flask was opened and the impression material was removed.

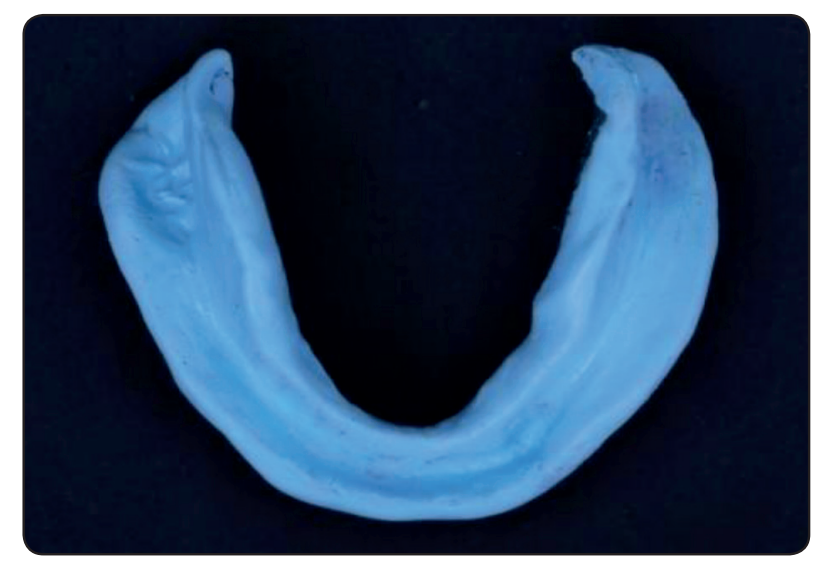

Fig. (1) Relining impression

The fitting surface of the dentures of group I was roughened and the Primo adhesive supplied in the kit was brushed 1-2 times onto the entire denture base and was left to dry for 60-90 minutes. Then, Molloplast B paste was taken by a clean spatula and applied onto the denture base. It was covered with cellophane paper and the flask was closed and pressed for approximately 4 minutes. Then, the flask was opened and the cellophane paper and excess material was removed. The flask was closed once more under press for approximately 15 minutes. The flask was placed after pressing in cold water and was heated up slowly to $100^{\circ} \mathrm{C}$. The polymerization in boiling water was done for one hour. The flask was cooled down slowly. After deflasking, special cutter burs for siliconebased liners were used to trim and finish the unfinished relined mandibular denture base borders at (15-20 thousand r.p,m) to avoid heat generation (Fig 2(a)).

In group II, the fitting surface of the denture was roughened and primed with liquid B monomer (hardener) of Versacryl material. In a small mixing cup, 42 drops of softener monomer were mixed with 8 drops of hardener monomer (relining proportions). Then, 1.5 parts of powder were added to 1 part liquid, by weight. The mixture was stirred until thick enough to be poured against primed acrylic denture base. The flask was closed, pressed and placed in cold water and was heated up slowly to $100^{\circ} \mathrm{C}$. The polymerization in boiling water was done for approximately one hour. The flask was cooled down slowly. Deflasking and finishing were carried out.

Relined mandibular dentures insertion was done in both groups. Denture extension, retention, stability and occlusion in centric relation were checked. Any needed adjustments were carried out. In group II, the patients were instructed to immerse the Versacryl relined dentures in $60^{\circ} \mathrm{C}$ warm water for 5 minutes before insertion to soften the material and provide the desired flexibility and softeness (Fig 2(b)). Oral health related quality of life was evaluated at two weeks, two months and four months using the Arabic version of OHIP-EDENT questionnaire ${ }^{11}$.

\section{Cytological smear and PAP staining procedure}

A cytological smear was collected from the mid crestal area of the mandibular residual alveolar ridge at the following appointments; prior to denture insertion and at all follow up periods using a wooden tongue depressor. The material was smeared on to a clean glass slide and immediately fixed in $95 \%$ ethyl alcohol.

After the smears were stained by the Papanicolaou stain (PAP), cytological examination of the PAP stained slides was carried out under the 


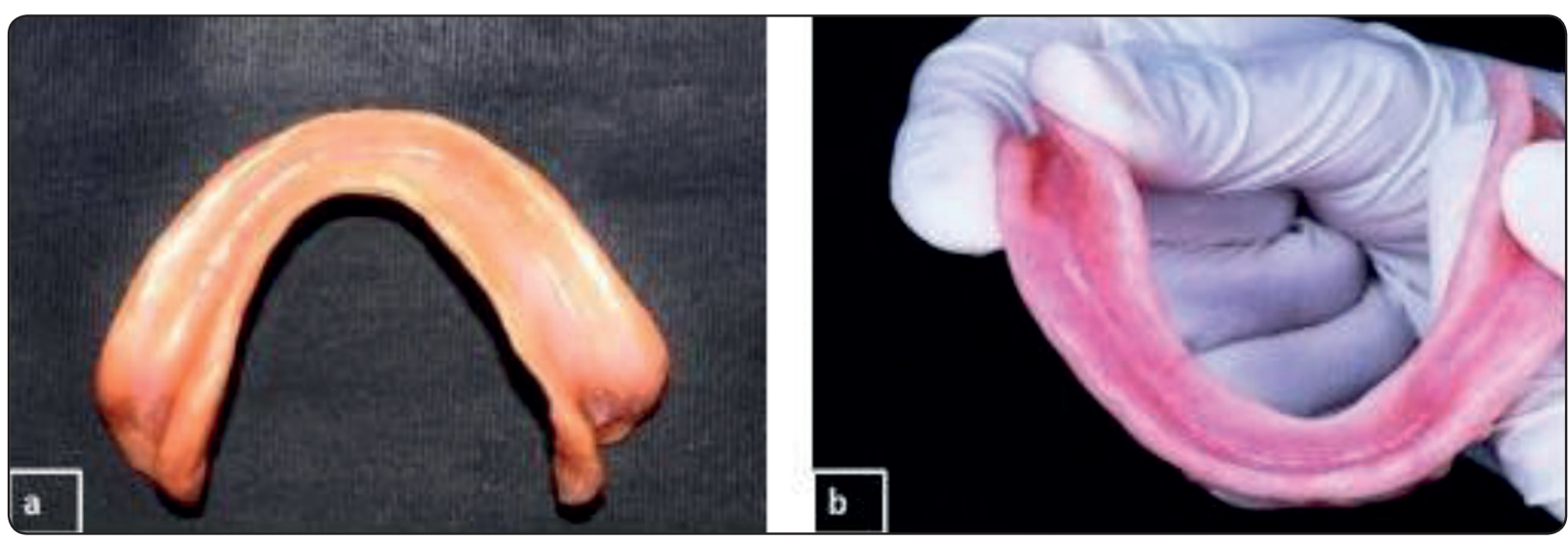

Fig. 2:(a) Finished Versacryl liner, (b) Versacryl lining material after 5 minutes immersion in warm water.

bright field light microscopy. An initial screening at magnification of $\mathrm{x} 100$ was made to choose the most cell rich fields. Further examination was done at magnification of $x 400$ to assess the fully keratinized anucleated cells (orthokeratinocytes) and the immature keratinized cells with pyknotic nuclei (parakeratinocytes). After PAP staining, keratinized cells (ortho or para) were seen stained respectively from brown to orange, while the parabasal cells were stained faint green to blue and the intermediate cells were stained pink.

The image analyzer computer system using the software Leica Quin $5000^{\tilde{N}}$ was used to measure the area percent of the orange to brown stained cells rep- resenting the ortho and para keratinized cells (total keratinization area percent) in relation to the total epithelial cell populations. In addition, the area percent of the orange to brown stained cells containing pyknotic nuclei representing the para-keratinized cells (para- keratinization area percent) in relation to the total epithelial cell population was measured. This was measured in a standard measuring frame using a magnification $\mathrm{x} 400$ by light microscopy transferred to the monitor's screen, These areas were masked by a blue color using the computer system (Fig 3). Area percent values for each group were obtained from 5 different fields from different slides. Values were presented as mean and standard deviation values and statistically analysed.

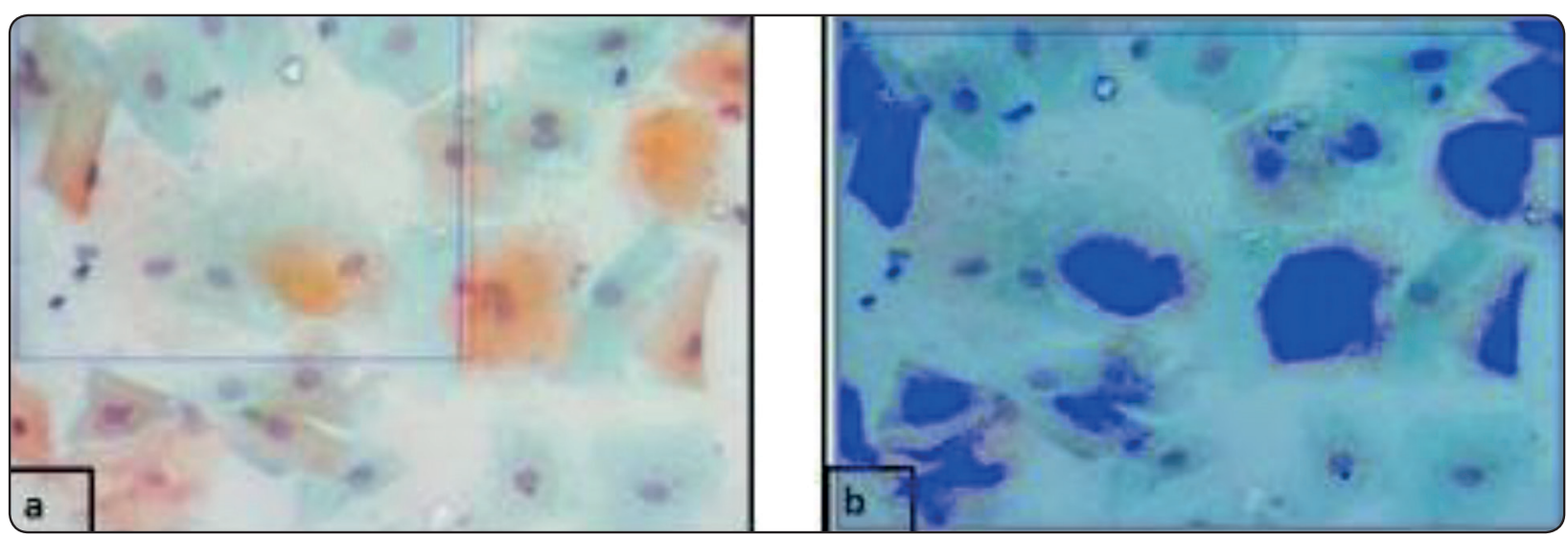

Fig. (3) A copy of display as seen on the monitor's screen of the image analyser showing keratinized cells before (a) and after (b) the blue color masking them. (PAP x400)

Ñ Leica Microsystems LTD. CH9435 Meerbrugg Type: DFC295 (12730469), Input:12v/170 MA, Serial number: 0557060916, Switzerland 


\section{Statistical analysis}

Comparison between the study groups was done using Mann Whitney U test for independent samples. Within each group, comparison was done using Wilcoxon signed rank test for paired samples. $P$ values less than 0.05 were considered significant. (Statistical Software Package R version 2.15.2 (26-10-2010).

\section{RESULTS}

\section{Clinical findings}

Results showed a significant improvement in oral health related quality of life in both groups at two weeks, two months and four months. The results showed that Versacryl liner provided a better oral health related quality of life at two weeks and two months than conventional MolloplastB liner and the difference was significant. While at four months, there was no difference between the two groups. (Fig 4)

\section{Histopathologic findings}

Microscopic examination of PAP stained cytological smears collected from the ridge mucosa at baseline in both groups showed few keratinized cells (orange stain), intermediate cells (pink stain) and parabasal cells (blue stain).(Fig 5(a))

For group I patients using mandibular dentures relined with MolloplastB dentures, after 2 weeks

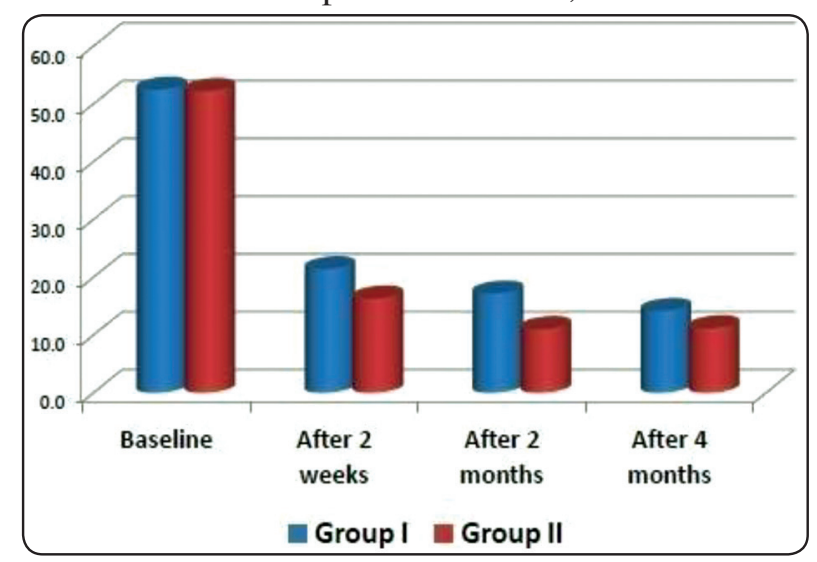

Fig. (4) Mean patient score of OHIP-EDENT Questionnaire in each follow up time in the two groups and 2 months, keratinized cell increased which were mainly parakeratinzed cells (brown stained shrunken cells having remenants of nuclei). At the end of the study (after 4 months), parakeratinized predominated. (Fig 5 (b, c \&d))

On the other hand, for group II patients using mandibular dentures relined with Versacryl, after 2 weeks and 2 months, keratinized cell increased which were mainly orthkeratinzed cells (brown stained shrunken cells without remenants of nuclei). At the end of the study (after 4 months), orthokeratinized predominated. (Fig $6(\mathbf{a}, \mathbf{b} \& \mathbf{c})$ ).

\section{Keratinzation}

In group I patients, there was a continuous increase in the mean total keratiniation and parakeratinization area percent in all follow-up intervals. This increase was statistically significant after 2 weeks, 2 months and 4 months compared to baseline. The mean, standard deviation and $\mathrm{P}$ values for these results are shown in (Table1 a $\& \mathbf{2}$ a). The increase in mean total keratiniation and parakeratinization area percent was statistically significant between each follow-up period and the previous one. (Table 1 b \& 2 b).

In group II patients, there was a continuous increase in the mean total keratinization area percent in all follow-up appointments. This increase was statistically significant after 2 weeks, 2 months and 4 months compared to baseline. The mean, standard deviation and $\mathrm{P}$ values for these results are shown in (Table 1(a)). This increase was also statistically significant between each follow-up period and the previous one (Table 1(b)). Yet, there was a continuous decrease in the mean parakeratinization area percent in all follow-up appointments. This decrease was not statistically significant after 2 weeks, while it was statistically significant after 2 months and 4 months compared to baseline. The mean, standard deviation and $\mathrm{P}$ values for these results are shown in (Table 2 (a)). This decrease in mean parakeratinization area percent was also statistically significant between '2months to 2 weeks' and ' 4 months to 2 months' follow-up periods (Table 2 (b)). 


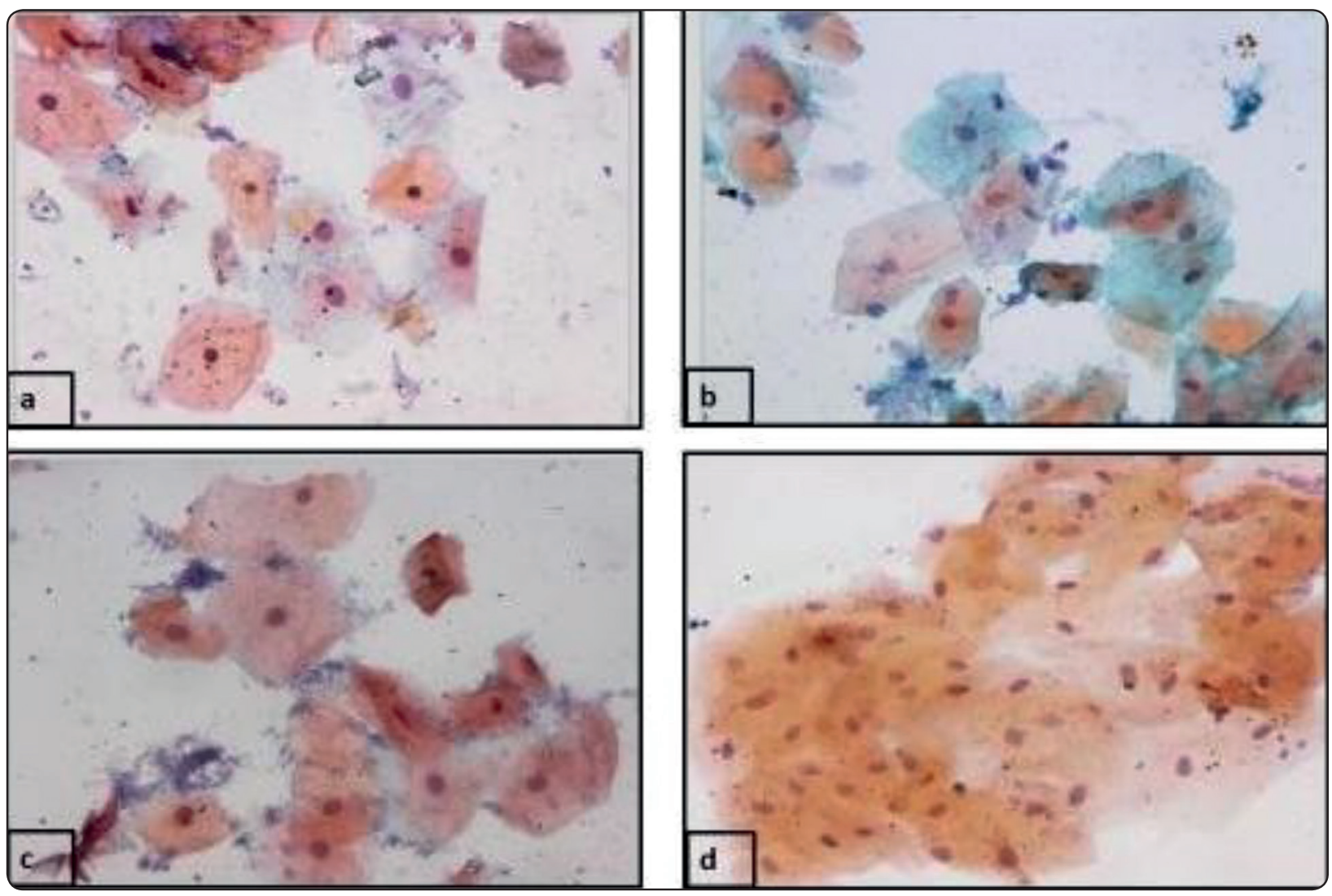

Fig. (5) Photomicrograph showing (a): few keratinized cells (orange stain), intermediate cells (pink stain) and parabasal cells (blue stain) for patients at baseline. (b\&c) many para and some ortho keratinized cells for group I patients after 2 weeks and 2 months, respectively, (d) predominating parakeratinized cells for group I patients after 4 months (PAP x 400).

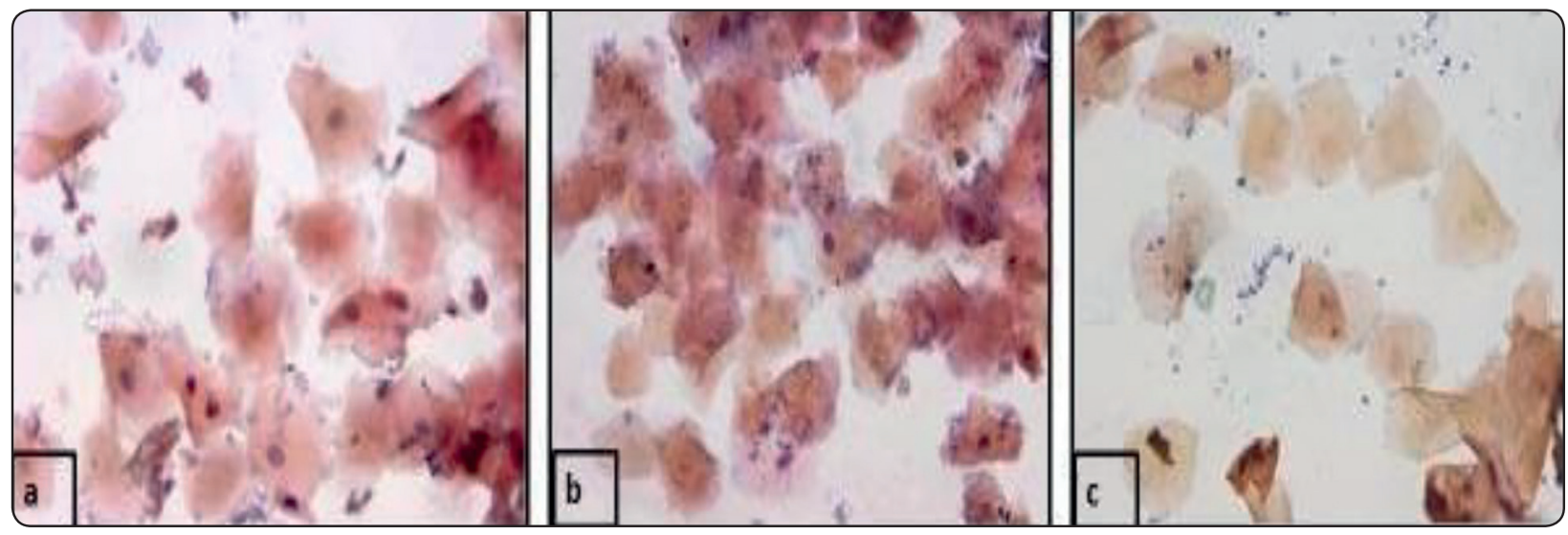

Fig. (6) Photomicrograph showing (a\&b): many ortho and some para keratinized cells for group II patients after 2 weeks and 2 months, respectively, (c) predominating orthokeratinized cells for group II patients after 4 months (PAP x 400). 
TABLE (1 A) The mean, standard deviation (SD), $\mathrm{P}$ value of mean total keratinization area percent in each time Period 'compared to baseline' in different groups.

\begin{tabular}{|c|c|c|c|c|c|c|c|c|c|c|c|}
\hline & \multicolumn{2}{|c|}{$\begin{array}{l}\text { Baseline } \\
\qquad(n=14)\end{array}$} & \multicolumn{3}{|c|}{$\begin{array}{l}\text { After } 2 \text { weeks } \\
\qquad(n=14)\end{array}$} & \multicolumn{3}{|c|}{$\begin{array}{l}\text { After } 2 \text { months } \\
\qquad(\mathrm{n}=14)\end{array}$} & \multicolumn{3}{|c|}{$\begin{array}{l}\text { After } 4 \text { months } \\
\qquad(n=14)\end{array}$} \\
\hline & Mean & $\mathrm{SD}$ & Mean & SD & P value & Mean & SD & $\mathrm{P}$ value & Mean & SD & $\mathrm{P}$ value \\
\hline Group I & 18.86 & 1.82 & 25.38 & 1.56 & $0.001 *$ & 29.46 & 1.58 & $0.001 *$ & 41.73 & 2.82 & $0.001 *$ \\
\hline Group II & 18.01 & 2.03 & 17.51 & 2.16 & 0.807 & 15.39 & 1.51 & $0.002 *$ & 11.91 & 2.04 & $0.001 *$ \\
\hline
\end{tabular}

*; significant $(p<0.05)$ ns; non-significant $(p>0.05)$

TABLE (1 B) P value of mean total keratinization area percent in each time Period 'compared to previous' in different groups

\begin{tabular}{|c|c|c|c|}
\hline & From 2 weeks to baseline & From 2 months to 2 weeks & From 4 months to 2 months \\
\hline Group I & $0.002 *$ & $0.002 *$ & $0.001 *$ \\
\hline Group II & $0.002 *$ & $0.001 *$ & $0.001 *$ \\
\hline
\end{tabular}

*; significant $(p<0.05)$ ns; non-significant $(p>0.05)$

TABLE (2 A) The mean, standard deviation (SD) of mean parakeratinization area percent in each time Period 'compared to baseline' in different groups

\begin{tabular}{|c|c|c|c|c|c|c|c|c|c|c|c|}
\hline & \multicolumn{2}{|c|}{$\begin{array}{c}\text { Baseline } \\
(\mathbf{n = 1 4})\end{array}$} & \multicolumn{2}{|c|}{$\begin{array}{c}\text { After 2 weeks } \\
(\mathbf{n = 1 4})\end{array}$} & \multicolumn{3}{c|}{$\begin{array}{c}\text { After 2 months } \\
(\mathbf{n = 1 4})\end{array}$} & \multicolumn{3}{c|}{$\begin{array}{c}\text { After 4 months } \\
(\mathbf{n = 1 4})\end{array}$} \\
\hline & Mean & SD & Mean & SD & P value & Mean & SD & P value & Mean & SD & P value \\
\hline Group I & 18.86 & 1.82 & 25.38 & 1.56 & $0.001 *$ & 29.46 & 1.58 & $0.001 *$ & 41.73 & 2.82 & $0.001 *$ \\
\hline Group II & 18.01 & 2.03 & 17.51 & 2.16 & 0.807 & 15.39 & 1.51 & $0.002^{*}$ & 11.91 & 2.04 & $0.001 *$ \\
\hline
\end{tabular}

*; significant $(p<0.05)$ ns; non-significant $(p>0.05)$

TABLE (2 B) P value of mean parakeratinization area percent in each time Period 'compared to previous' in different groups.

\begin{tabular}{|c|c|c|c|}
\hline & From 2 weeks to baseline & From 2 months to 2 weeks & From 4 months to 2 months \\
\hline Group I & $0.001^{*}$ & $0.001^{*}$ & $0.001^{*}$ \\
\hline Group II & $0.807^{*}$ & $0.009^{*}$ & $0.001^{*}$ \\
\hline
\end{tabular}

*;significant (p<0.05) ns; non-significant $(p>0.05)$ 


\section{DISCUSSION}

OHIP-EDENT questionnaire has been used to evaluate the effect of complete denture relining on quality of life of complete denture wearers ${ }^{12}, 13$. The Arabic version of the OHIP questionnaire was adopted and the answers to these questions are a clear indication of how patients feel about their dentures after relining ${ }^{11}$.

The exfoliataive cytology method used in this study offers a simple, rapid and non-invasive technique compared to other techniques such as partial or full thickness biopsies that interfere with the tissue healing process. The digital image analyzer computer system method was used in this study to measure the degree of keratinization of the PAP stained smears that avoids the effect of human subjectivity evidenced in manual microscopical analysis, therefore it enhances both precision and reproducibility of the results with less time and effort. ${ }^{14}$

This study shows a significant difference between the two groups regarding oral health related quality of life favoring the mandibular dentures relined with versacryl which may be due to the presence of surface roughness in the mandibular dentures relined with molloplast- B as the silicone-based liners are more difficult to finish ${ }^{15}$. The rubbing action of this roughness on the underlying mucosa can lead to more patient complaint. Furthermore, these results are consistent with authors who claim that surface roughness of silicone-based liners increase with the duration of usage due to the effect of denture cleansers and brushing ${ }^{16}{ }^{17}$.Furthermore, there is also the problem of weak adhesion between denture base and silicone-based liners which creates an environment that renders bacterial or fungal colonization and also compromise the durability of the soft liner ${ }^{18}$.

While after 4 months the difference between the two groups was not significant. These results are consistent with a study that found that some patients may take up to 6 months to achieve optimal use with their new mandibular dentures and they complain less as the period of usage increases ${ }^{19}$. Another study concluded that patient satisfaction with dentures improves over time and the initial clinical quality of dentures at insertion isn't an important factor in determining the long term patients' satisfaction ${ }^{20}$.

Regarding tissue keratization, the results of this study revealed a significant increase in the total keratinization area percent after 2 weeks, 2 months and 4 months after mandibular denture relining with molloplast-B and Versacryl liners. This was in accordance to a study that found a significant increase in the keratinization for patients with stable dentures. This indicates that denture builds keratinization underneath by frictional masticatory forces ${ }^{21}$. This explanation was also supported by another study reported that the absence of the frictional masticatory force leaded to a decrease in ridge keratinization ${ }^{22}$. The study found a decrease in ridge keratinization under anterior partial dentures after six months of denture use than that at the time of denture delivery due to keeping the examined anterior partial dentures completely out of occlusion in centric occluding relation as well as from centric to any other eccentric position. Other showed decreased keratinization following the use of removable prostheses. ${ }^{23}$

Regarding the para-keratinization area percent, there was a significant increase at all follow-up periods in molloplast-B relined mandibular dentures group while there was a significant decrease in the Versacryl relined mandibular denture group. The increase in para-keratinization is related to fungal and bacterial colonization in the molloplast-B liner group. On the other hand the increase in ortho-keratinization in Versacryl liner group is related to denture frictional effect. This difference was discussed at a study that found that ridge keratinization is not a simple mucosal reaction to loading, but it has many types and causes. It could be either ortho- keratinized which results mainly 
from loading or frictional effects of the denture tissue surface against the ridge mucosa or mainly para-keratinized that results from microorganisms and bacterial colonization on the tissue surface of the removable prosthesis. ${ }^{24}$

Comparing tissue keratinization of the two groups, there were significant difference in total keratinization area percent and para- keratinization area percent in all time intervals. These results are in accordance to a study that stated that changes in the degree of keratinization differed depending on the type of material used for the denture fabrication ${ }^{25}$.

In this study, the molloplast-B liner did not provide a proper hygienic environment due to surface roughness and poor bonding to the denture base that helped in fungal and bacterial accumulation and inflammation which was manifested by a significant increase in the para-keratinization area percent. However, in patients using Versacryl relined denture a significant decrease in the para-keratinization area percent was found.

\section{CONCLUSION}

Versacryl liner showed better oral health related quality of life than conventional Molloplast-B liner and it should be adopted to reline mandibular dentures in patients with atrophic ridges as it provides prolonged and optimum soft tissue reaction (orthokeratinization) together with a remarkable improvement in patient's quality of life.

\section{REFERENCES}

1. Murata H, Hamada T, Sadamori S. Relationship between viscoelastic properties of soft denture liners and clinical efficacy. Japanese Dental Science Review. 2008 Oct $1 ; 44(2): 128-32$.

2. Singh O, Kaur R, Nanda S, Sethi E. Residual ridge resorption: A major oral disease entity in relation to bone density. Indian Journal of Oral Sciences. 2016 Jan $1 ; 7(1): 3-6$.
3. Kimoto S, Kimoto K, Gunji A, Kawai Y, Murakami H, Tanaka K, Syu K, Aoki H, Toyoda M, Kobayashi K. Clinical effects of acrylic resilient denture liners applied to mandibular complete dentures on the alveolar ridge. Journal of oral rehabilitation. 2007 Nov;34(11):862-9.

4. Chladek G, Żmudzki J, Kasperski J. Long-term soft denture lining materials. Materials. 2014 Aug;7(8):5816-42.

5. Walvis M. Versacryl. TandartsPraktijk. 2005 Aug 1; 26(8):642-6.

6. Ramadan A, Moussa A, Yehia D, Zaki I, Wael A, Zeid A. Viscoelastic properties of Thermo-Elastic resin reline with different ratios. J Appl Sci Res. 2012;8(3):1477-1483.

7. Budtz-Jorgensen E: Oral mucosal lesions associated with the wearing of removable dentures. J. Oral Pathol., 10:6580,1981 .

8. Tolboe H, Isidor F, Budtz-Jörgensen $\mathrm{E}$ and Kaaber S: Influence of oral hygiene on the mucosal conditions beneath bridge pontics. Scand. J. Dent. Res., 95(6):475482, 1987.

9. Kapur K, Shklar G :The effect of complete dentures on alveolar mucosa. J. Prosthet. Dent., 13(6):1030-1037, 1963.

10. Akal UK, Mocan A, Aydoğan S, Oygür T, Bağci L, Camdeviren H: Keratinization of palatal mucosa beneath metal-based removable partial and acrylic-based complete dentures compared with normal palatal mucosa:a clinical, cytological and histological study. J. Marmara.Univ. Dent. Fac., 2(4):665-672, 1997.

11. Alqutaibi AY; M.F. Abdullah and A.F Kaddah. Impact of single versus two Implants-retained Mandibular Overdentures on quality of life and EMG Activity for completely edentulous patients (RCT): 2016.

12. Pisani MX, Malheiros-segundo ADL, Balbino KL, et al. Oral health related quality of life of edentulous patients after denture relining with a siliconebased soft liner. Gerodontology. 2012;29(2):474-480.

13. KRUNIC, NEBOJSA,ET AL. Oral health-related quality of life of edentulous patients after complete dentures relining. Vojnsosanitetski pregled,2015,72(4): 307-311.

14. Lopez XM, Debeir O, Salmon I, Decaestecker C. Whole slide imaging and analysis for biomarker evaluation in digital pathology. Microscopy: advances in scientific research and education. 2014;2:776, 
15. Nevzatoğlu EU, Özcan M, Kulak-Ozkan Y, Kadir T. Adherence of Candida albicans to denture base acrylics and silicone-based resilient liner materials with different surface finishes. Clinical oral investigations. 2007 Sep $1 ; 11(3): 231-6$.

16. Jin C, Nikawa H, Makihira S, Hamada T, Furukawa M, Murata $\mathrm{H}$. Changes in surface roughness and colour stability of soft denture lining materials caused by denture cleansers. Journal of oral rehabilitation. 2003 Feb; 30(2):125-30.

17. Oliveira LV, Mesquita MF, Henriques GE, Consani RL. The effect of brushing on surface roughness of denture lining materials. Journal of Prosthodontics. 2007 May;16(3): 179-84.

18. Nikawa H, Jin C, Makihira S, Egusa H, Hamada T, Kumagai H. Biofilm formation of Candida albicans on the surfaces of deteriorated soft denture lining materials caused by denture cleansers in vitro. Journal of oral rehabilitation. 2003 Mar;30(3):243-50.

19. Farias-Neto A, Carreiro AF. Changes in patient satisfaction and masticatory efficiency during adaptation to new dentures. Compend Contin Educ Dent. 2015 Mar; 36(3): 174-7.
20. Fenlon MR, Sherriff M. Investigation of new complete denture quality and patients' satisfaction with and use of dentures after two years. Journal of Dentistry. 2004 May 1;32(4):327-33.

21. Mneizel T: Astudy of the palatal keratinization levels beneath complete acrylic resin dentures. JRMS, 12 (1):2529, 2003.

22. Aziz EA, Amin NR. The effect of two protective occlusal schemes of immediately loaded mini-implant supported mandibular overdenture on masseter muscle. E.D.J. 2015; 61(3):145.

23. Harinasuta S, Howlett JA. Keratinization of palatal mucosa beneath metalbased removable partial dentures. J Dent. 1992; 20(3):152-155

24. Aziz EA, Amin NR. Cytological study of mucosal tissue reaction to different modern interim esthetic restorations.E.D.J. 2014;61(3):145.

25. Łukomska-Szymańska M, Brzeziński PM, Zieliński A, Sokołowski J. Cytological response of palatal epithelium to TiN-coated CoCr alloy denture. Folia histochemica et cytobiologica. 2012;50(1):104-10. 